\title{
The American Labour Movement in Transition
}

\author{
Ronald Miller*
}

\begin{abstract}
For the next three to five years, there appears to be little likelihood that the status of unions in the United States will change. The major forces that have economically and politically weakened organised labour persist. Because American unions are reactive and protective organisations, they have adjusted slowly and cautiously to shaping forces. Nevertheless, in response to changes in industrial structure, labour force composition and union leadership, fewer, larger, and internally diverse unions are evolving. To varying degrees, unions are reorienting their strategies and activities to reflect the interest of a work force that increasingly values co-operation rather than confrontation, employment security through managed change, and participative management. As a consequence, the industrial relations system is evolving a complex mixture of adversarial and co-management relationships.
\end{abstract}

Since the mid-1950s, unions in the United States have been struggling to stem the erosion of their economic and political power. The intervening years have not been kind to the labour movement. The United States ranks with France in having the lowest union density rate among industrialised nations (Chang, 1991 and Bean, 1992). It is small consolation for American unions that most national labour movements are also in decline.

A profile of the labour movement indicates that a substantial consolidation among unions is under way; fewer, larger, and internally diverse unions are evolving. With limited success to date, the labour movement is placing increased emphasis on organising activities among manual, clerical, and technical employees in service industries.

The factors that are reshaping the American labour movement are reviewed. This background provides the basis to: (1) assess the evolution of organised labour in an economy dominated by service, high-technology, and upgraded-technology industries, and (2) explore an industrial relations system in transition. Additionally, developments in the American labour movement and industrial relations system may provide some insight to future changes in New Zealand and Australia. ${ }^{1}$

\footnotetext{
* $\quad$ Professor, College of Business, Oregon State University
}

Union density estimates are based primarily on data from the Current Population Survey (CPS), a monthly survey of households conducted by the US Bureau of the Census. Additional data on union membership, density, and employment has been obtained from Employment and Earnings, published monthly by the US Bureau of Labor Statistics, and the bi-annual reports of the Executive Council, AFLCIO. Michael Curme, Barry Hirsch and David MacPherson have produced leading studies utilising the CPS data (Curme, 1990 and Hirsch, 1996). 


\section{Labour movement profile}

Union membership as a percentage of the civilian labour force reached a high point of 34 percent in 1955, and has declined ever since. In 1995, union membership density stood at 14.9 percent among private and public employees. A significant difference exists between union membership in the private sector, 10.3 percent, and the public sector, 37.7 percent.

Table 1: Union membership, representation and density, 1985 and 1995

\begin{tabular}{|c|c|c|}
\hline & $\begin{array}{c}\text { Membership/ } \\
\text { Percent }\end{array}$ & $\begin{array}{c}\text { Representation/ } \\
\text { Percent }\end{array}$ \\
\hline All workers 1985 & & $19,358,100 / 20.5$ \\
1995 & $16,996,100 / 18.0$ & $18,346,300 / 16.7$ \\
\hline Private sector & $16,359,600 / 14.9$ & $12,437,500 / 15.9$ \\
1985 & & $10,359,800 / 11.3$ \\
\hline 1995 & $11,253,000 / 14.3$ & \\
1985 & $9,432,100 / 10.3$ & $6,920,600 / 43.1$ \\
\hline Public sector & & $7,986,600 / 43.5$ \\
\hline
\end{tabular}

Source: US Bureau of the Census, Current Population Survey

During the 1985-1995 period, membership density increased modestly in the public sector and declined significantly in the private sector. The relative sizes of the two sectors should be kept in mind. All government units (federal, state, local) employ 18.3 million workers, while private enterprises employ 91.6 million workers.

It should be noted that union membership and union representation differ. Due to legal obligations associated with a union serving as the exclusive representative of a bargaining unit, a union must represent workers in a bargaining unit who have not joined the union. As a consequence, unions seek compulsory union membership provisions in collective bargaining agreements that force so-called "free riders" to become union members. Many private sector employers oppose compulsory union membership, 21 states prohibit compulsory union membership in private employment (right-to-work laws), and constitutional issues bar compulsory union membership in most government units. Therefore, especially in the public sector, unions represent and bargain for workers who are not dues paying members.

Table 2 presents some demographic characteristics of union membership. Certain patterns have persisted for decades, such as unionisation is higher among men than women, and among blacks than whites. Black men have the highest union membership, 23 percent, while white women have the lowest, 11 percent. Overall, declining union density in manufacturing and construction has significantly lowered unionisation rates for black and white men, and for 
workers with only elementary and high school educations. Significantly, by 1993, for the first time in the nation's history, unionisation among college graduates is above the level for all workers.

Table 2: Demographic characteristics of union membership, 1985 and 1995

\begin{tabular}{|l|c|c|}
\hline & $\begin{array}{c}\text { Percentage } \\
1985\end{array}$ & $\begin{array}{c}\text { Percentage } \\
1995\end{array}$ \\
\hline All workers & 18.0 & 14.9 \\
Men & 22.1 & 17.2 \\
Women & 13.2 & 12.3 \\
Whites & 17.3 & 14.2 \\
Blacks & 24.3 & 19.9 \\
Other & 16.5 & 14.9 \\
Schooling 0-11 years & 17.8 & 10.5 \\
Schooling 12 years & 20.6 & 16.5 \\
Schooling 13-15 years & 15.3 & 14.4 \\
Schooling 16+ years & 16.6 & 15.5 \\
\hline
\end{tabular}

Source: US Bureau of the Census, Current Population Survey

There are 133 labour organisations (including professional employee associations) headquartered in the United States (Gifford, 1996). In 1995, these labour organisations reported a total membership of 16.3 million workers. Forty United States based unions have affiliated organisations and members in Canada. In recent years, Canadian members of some US based international unions have withdrawn to form separate unions for Canadians only. Most notably, in 1984, the Canadian members of the United Auto Workers withdrew to form their own organisation. There are indications that the Teamsters Union is heading in the same direction. Although closer economic integration of Canada and the United States argues for the maintenance of mixed membership, the realities of Canadian nationalism and minority status within US based unions lead to separation.

The American Federation of Labor-Congress of Industrial Organization (AFL-CIO) is the country's only major union federation. The AFL-CIO is primarily a political action organisation at the federal, state and local levels of government. Although closely allied with the Democratic Party through financial support and the election of delegates to party conventions, the AFL-CIO guards its prerogative to "reward friends and punish enemies". The AFL-CIO engages in a broad spectrum of political activities from get-out-the-vote campaigns in local government and state-wide elections to lobbying in Congress. Additionally, it disseminates policies developed by leaders of its affiliated unions, assists in co-ordinating union organising drives, conducts research and training activities, and represents organised labour in international forums. As of 1996, the 78 unions affiliated with the AFLCIO reported total paid membership of 13 million. The high point in AFL-CIO membership, 
14 million, was reached in 1975. Subsequent to the merger of two federations in 1955 , the number of affiliated unions has declined from 141 to 78 . In recent years, the pace of mergers has quickened as memberships dwindle, operating budgets decline, old rivalries become irrelevant, and new administrative techniques are adopted. Clearly, the direction is toward fewer, but larger unions.

Since 1975, 54 percent of union mergers have been between AFL-CIO unions, 40 percent have been between an independent union and an AFL-CIO union, and only six percent have been between two independent unions (Williamson, 1995). Most union mergers have been absorptions, usually by a larger and/or more affluent organisation. During the past ten years, the most active unions in absorption-type mergers have been the Service Employees International Union, the International Association of Machinists, the United Food and Commercial Workers, and the Communication Workers of America. In contrast to absorption, the 1995 merger between the Amalgamated Clothing Workers Union (129,000 members) and the International Ladies Garment Workers Union (123,000 members) created a new union called UNITE (Union of Needletrades, Industrial and Textile Employees). A mega-merger is tentatively scheduled for the year 2000 among the United Auto Workers $(751,000$ members), the United Steelworkers of America (403,000 members), and the International Association of Machinists (448,000 members). The organisational structure of the new entity and the extent of retained identity of the three unions are currently being negotiated.

The changing composition and size of unions affiliated with the AFL-CIO reflects the restructuring of the United States economy. The pattern is one of expansion by unions in the government and service sectors, and retrenchment among unions based in manufacturing. A consequence of the economic realities that confront unions is that historical jurisdictional boundaries no longer constrain most unions; they organise where opportunities arise. For example, the United Auto Workers has conducted organising drives at universities, state government agencies, hospitals, and publishers. Table 3 lists the ten largest unions in the AFL-CIO; together, these ten unions account for almost 60 percent of the AFL-CIO's total membership.

Table 3: Ten largest unions in AFL-CIO, 1995 membership

\begin{tabular}{|l|r|}
\hline International Brotherhood of Teamsters & $1,285,000$ \\
American Federation of State, County and Municipal Employees & $1,183,000$ \\
Service Employees International Union & $1,027,000$ \\
United Food and Commercial Workers & 983,000 \\
United Automobile Workers & 751,000 \\
International Brotherhood of Electrical Workers & 679,000 \\
American Federation of Teachers & 613,000 \\
Communication Workers of America & 478,000 \\
International Association of Machinists & 448,000 \\
United Steelworkers of America & 403,000 \\
\hline
\end{tabular}

Source: Report of the Executive Council, AFL-CIO, 1995 
The largest American union, the National Education Association (NEA) with 2.1 million members, is not a member of the AFL-CIO. The NEA primarily represents public sector teachers. Because the NEA already exercises very effective political influence at all levels of government, there is little incentive for it to join and pay membership fees to the AFLCIO. Merger discussions between the NEA and the American Federation of Teachers (AFT), an AFL-CIO affiliate, have been on and off for decades. For a variety of economic, policy, and political reasons, other unions have not affiliated with the AFL-CIO, such as: American Nurses Association (205,000 members); National Fraternal Order of Police $(250,000$ members); and the California School Employees Association (112,000 members).

With the re-affiliations of the United Automobile Workers in 1981, the Teamsters in 1987, and the United Mine Workers in 1990, the AFL-CIO is more cohesive today than anytime since the 1930s. Nevertheless, as the Federation and the American labour movement adapt to the realities of an internationalised, service-based, and technology intensive economy, the challenges are substantial.

\section{Forces impacting the labour movement}

Reflective of long-term structural changes in the American economy, employment has declined in former centres of union strength, such as manufacturing, and expanded in lightly unionised service industries. By 1995, 72.1 million workers were employed in private sector, non-manufacturing industries compared to 19.5 million workers in manufacturing. The restructuring of firms and industries through down-sizing, mergers, bankruptcies, technological innovations, and relocations devastated some unions. For example, between 1975 and 1995 , the United Steelworkers of America, a former powerhouse of industrial unionism, lost 62 percent of its membership, dropping from 1,062,000 to 403,000. As a consequence, the union is attempting to stabilise itself through mergers with other unions (such as the United Rubber Workers) and organising activities among hospital workers, bank employees, and other service sector workers.

The long period of economic recovery and prosperity that took hold in the mid-1980s did not help manufacturing employment or union membership. Regions of high unemployment persisted. The ranks of the unemployed provided employers with a ready supply of strike breakers and replacement workers. America has not suffered de-industrialisation, rather it has experienced large-scale de-unionisation of its industrial base. Table 4 presents data on union membership density in selected industries.

Compounding the problems for most unions, employment growth has been largely confined to small firms (Wiatrowski, 1994). In the private sector, 56 percent of all employees work for firms that employ fewer than 100 persons. Workers in such firms are expensive for unions to organise and represent. Companies with 19 or fewer workers accounted for 78 percent of job growth between 1987 and 1992. Moreover, companies with fewer than 100 workers accounted for virtually all net job growth across all private employment sectors of the economy. Small-scale firms in the service industries experienced the greatest growth. 
Table 4: Union membership density, selected industries, 1985 and 1995

\begin{tabular}{|l|c|c|}
\hline & Percentage & Percentage \\
\hline Aircraft and parts & 1985 & 1995 \\
Air transportation & 33.8 & 31.1 \\
Chemicals (industrial) & 40.4 & 38.5 \\
Clothing and Apparel & 19.0 & 17.7 \\
Coal mining & 23.0 & 14.2 \\
Computer equipment & 45.3 & 33.8 \\
Construction & 4.6 & 2.1 \\
Construction equipment & 23.1 & 18.9 \\
Electrical machinery & 24.8 & 22.3 \\
Finance, insurance, real estate & 17.8 & 9.2 \\
Hospitals & 3.5 & 2.8 \\
Medical and dental equipment & 14.7 & 14.0 \\
Motor vehicles and equipment & 8.2 & 6.1 \\
Pharmaceutical & 57.3 & 42.9 \\
Printing and publishing & 9.7 & 6.3 \\
Railroads & 13.5 & 8.1 \\
Retail trade & 82.1 & 74.8 \\
Steelworks & 7.2 & 6.0 \\
Telephone communications & 57.9 & 48.7 \\
Tyres & 49.9 & 32.7 \\
Trucking services & 45.0 & 33.3 \\
Utilities (electric) & 30.3 & 21.3 \\
Wholesale trade & 39.8 & 32.7 \\
\hline
\end{tabular}

Source: US Bureau of the Census, Current Population Survey

The continuing trend in the manufacturing sector is especially disturbing for unions. Manufacturing companies with 100 or more workers shrank by 3.4 percent from 1987 to 1992, while smaller manufacturing firms grew by 13.4 percent.

Heightened domestic and international competition has been an integral aspect of the restructuring of the American economy and the labour movement. Deregulation in the trucking, communications, and airline industries dramatically changed the economic and industrial relations characteristics of those industries. Competition among established firms and new entrants significantly increased. In the communications, trucking and airline industries, many new firms operate non-union, and because of lower wage rates and no union imposed work restrictions, these firms operate at a cost advantage. Down-sizing for survival has become the norm. Bankruptcies have also taken a heavy toll. With the removal of the protected environment of government regulation, union membership in these industries sharply declined. For example, the Teamsters union suffered a loss of almost a million members between 1975 and 1995; its current membership is 1.3 million. 
Since the 1970s, heightened competition between unionised and nonunion firms has spread throughout the economy. This trend is clearly evident in the mining and constructions industries. The United Mine Workers union continues to battle coal mining companies to limit subcontracting work to small, nonunion firms. In the construction industry, many contractors operate fully non-union, and others maintain separate union and non-union divisions. Changes in technology and material have facilitated the growth of non-union construction. Segments of the industry, especially residential construction and urban rehabilitation, and some trades, such as drywalling, painting, and roofing, now largely operate non-union. Overall, union membership in the construction industry has declined from 23.1 percent in 1985 to 18.9 percent in 1995.

To the consternation of unions, the expansion of firms operating non-union occurred at the same time that the growth of international trade induced American firms to shift production out of the country, and foreign firms to challenge markets in the United States. Non-union manufacturers, especially at the high-tech end of the scale, have survived intense competitive conditions, and in so doing, have steadily transformed the American industrial base. Meanwhile, domestic production in some industries disappeared (electronics), substantially scaled back (clothing), or underwent basic restructuring (steel).

The automobile industry experienced the full force of international competition. Japanese firms (that are extensively unionised in their home country) mostly operate non-union plants in America, despite repeated organising drives by the United Automobile Workers. It should be noted, in situations such as the organising drives at Honda, workers voted not to be represented by the United Automobile Workers. The cumulative impact of heightened competition, new technology, down-sizing, and non-union operations has reduced membership in the United Auto Workers from 1,100,000 in 1975 to 751,000 in 1995. The United Rubber Workers, a companion union to the United Automobile Workers, also struggled to deal with imported tires, domestic non-union manufacturers, and foreign firms who now operate plants in the United States and dominate the industry. Membership in the United Rubber Workers fell dramatically from 173,000 in 1975 to 79,000 in 1995 . These examples illustrate why industrial unions were at the forefront of the unsuccessful legislative battles to prevent passage of the North American Free Trade Agreement and the General Agreement on Tariffs and Trade.

During the 1970s and 1980s, union representation and membership expanded rapidly among government workers. Union density remains high among public employees, such as postal workers (75 percent), elementary and secondary school teachers (58 percent), police (60 percent), and fire fighters (70 percent). However, in the $1990 \mathrm{~s}$, budget constraints and mounting taxpayer demands for leaner governments are forcing down-sizing at all levels of government. Lay-offs, privatisation of services, and programme reductions severely limit the potential for future union growth in this sector. Even in centres of traditional union strength, such as New York and Chicago, public sector unions are reluctantly accepting employment cutbacks. Nevertheless, the public sector remains a stronghold of union strength in an increasingly troubled labour movement.

Structural changes in the American economy alone do not explain the overall decline of the American labour movement. Employers have taken advantage of product and labour market 
conditions to aggressively resist union organising, and to press advantages in negotiations. This economic militancy has been augmented by a heightened use of legal tactics that limit the advantages that labour laws and administrative procedures have traditionally provided to unions. Employers characterise the results as "levelling the playing field". Unions contend that legal protection for organising and bargaining have been thwarted. In particular, employers have made effective use of replacement workers (strike breakers) to weaken union bargaining power, as in the long and bitter dispute between the Caterpillar Corporation and the United Auto Workers. By and large, the courts have supported employer actions under current labour law. Unions, and their political allies, have been unable to enact legislation to restrict the use of replacement workers.

\section{Union political power}

The failure of organised labour to gain favourable changes in the National Labor Relations Act is symptomatic of its weakened political position. While union endorsed candidates are often elected to office, legislative outcomes on important issues increasingly are going against organised labour's interests.

Union political power at the national level reached a post-World War peak in the 1960 s, especially during the years of close working relationships between President Johnson and the Democratic controlled Congress. Subsequently, divisive factions within the party, and bitter disputes among former political allies, weakened organised labour's political power. Even during the years of President Carter and a Democratic Congress (late 1970s), organised labour accomplished little of its legislative agenda. Insult was added to injury when large numbers of unionists twice voted for the popular Republican President Reagan.

With the election of a Democratic President and Congress in 1992, unions believed that their legislative prospects had significantly improved. This would not be the case. During the two years (1993 and 1994) that the Democratic party controlled the White House and Congress, little of organised labour's legislative agenda was achieved. Alliances of Republicans and conservative Democrats repeatedly stifled labour's agenda. Passage of the North American Free Trade Agreement and the General Agreement on Tariffs and Trade in the face of intense union opposition, and the inability of organised labour to obtain legislative restrictions on the permanent replacement of striking workers, say volumes about the status of its political power in Congress.

In retaliation for their losses, unions vowed to withhold re-election support from those Democratic senators and representatives who voted for the North American Free Trade Agreement. However, these threats were abandoned as unions attempted to limit Republican gains in the 1994 elections. Sweeping victories by Republicans in the congressional elections of 1994 ended any immediate hopes among unionists for legislative changes that would assist their organising and bargaining activities.

Union political influence has also suffered from the general weakening of internal political party discipline, and the growth of political action committees in financing campaigns 
(Delaney, 1991). Unions and employers cannot contribute directly to federal candidates, but they can form political action committees that are authorised to raise and spend voluntary contributions on behalf of those candidates. The number of political activities financed by businesses dwarfs those financed by unions. Moreover, in the 1994 congressional elections, candidates endorsed by organised labour were severely hurt by very low voter turnout among those special interest groups that traditionally support liberal Democratic candidates.

Over the years, organised labour's political influence has been most effective for measures that benefit workers and society in general (minimum wage legislation, occupational health and safety legislation, and civil rights legislation) and least effective for measures that benefit unions' narrower, special interests. Even in those instances where organised labour's political support contributed significantly to the passage of legislation beneficial to most workers, such as the Family and Medical Leave Act of 1993, the labour movement has received little public recognition.

Organised labour's political frustrations at the national level are in sharp contrast to the influence of unions within many state and local governments. State legislation authorising collective bargaining among public employees has contributed to the development of powerful lobbying programmes by public sector unions, especially the National Education Association (2.2 million members), and the American Federation of State, County and Municipal Employees (1.2 million members). Private sector unions also exercise substantial influence on state and local legislative bodies in support of worker disability compensation, unemployment compensations, public financed construction, and building codes.

In 1993, unionists anticipated that the "reform" agenda of the new chairman of the National Labor Relations Board, William Gould, would strengthen the hand of unions in dealing with employer avoidance strategies and result in more union victories in representation elections. However, following the 1994 elections, Republicans control the agency's budget and personnel appointments to policy making positions within the agency. This control gives the business community political influence to shape the "reform" agenda. Furthermore, the Republican Congress will significantly influence the appointment of federal judges, and thereby diminish the prospects for judicial relief for organised labour in its disputes with employers. Unless the congressional elections in 1996 reverse the 1994 results, organised labour can expect little assistance from the federal government to improve its status.

If the American labour movement is to be strengthened and renewed, it cannot rely upon supportive, federal government policies. For decades, organised labour emphasised political action to obtain government assistance to moderate employment losses, to weaken avoidance activities by employers during union organising campaigns, and to diminish employer economic power during bargaining and strikes. Unions have little to show for their money and efforts, except that adverse legislation was prevented.

Given that bargaining and political activities are increasingly interdependent, unions will not abandon their broad spectrum political activities. During the 1996 congressional and presidential elections, the AFL-CIO has committed $\$ 35$ million to the defeat of Republican candidates and the re-election of President Clinton. Organised labour is playing more of a role in the political process than it has since 1984 when it dominated the presidential 
campaign of Walter Mondale (who lost mightily to Ronald Reagan). Should the Democrats regain one or both chambers of Congress, and retain the White House, organised labour will be in a good position to again press its legislative agenda.

\section{Union organising}

To stem the decline in membership, unions must revise and substantially increase their organising activities. Unions cannot wait for changes in law and administrative procedures. Unions frequently blame the mediocre results in representation elections on the forcefulness of employer anti-union campaigns and unfair application of labour legislation. Certainly, provisions of the National Labor Relations Act could be more union-friendly. Nevertheless, under both Democratic and Republican administrations, union win percentages have declined. By 1994, the union win rate had stabilised at 49 percent. It is apparent that many workers involved in elections do not believe that union representation would sufficiently benefit them. Aggressive union avoidance programmes by employers have successfully shaped employee attitudes. Frustrated with the turn of events, unions repeatedly asked Congress for relief; to date, none has been forthcoming.

For many years, union leaders have blamed the labour movement's troubled condition on unsympathetic politicians and hostile employers. Rather, much of the fault for the low status of the labour movement rests with unions themselves. Only about five percent of the dues collected each year by American unions goes to organising new members. Reversing the decline in unionisation will take not only a commitment of substantially more money for organising efforts, but an admission by labour movement leaders that past priorities have failed. The decline in union organising activities over many years was based on policy decisions, not financial limitations. For many unions, finances have not declined as union membership has shrunk (Bennett, 1991). Unions have been utilising their assets for purposes other than organising. To survive in the long run, unions must be willing to risk substantial amounts of money for organising in the short run.

With the election of John Sweeney as the AFL-CIO's new president, a sea change has occurred in the attention given to organising activities. The new leadership of the AFL-CIO has made the training of organisers, the co-ordination of organising campaigns and the financing of organising activities as its top priorities. The successful "Justice for Janitors" organising campaign in Southern California is often cited by union advocates as an example of new life for the labour movement. However, a more significant feat for unions would be to demonstrate that they can move the vast and largely unorganised white-collar workforce to collective representation.

In support of renewed commitments to organising, some unions have effectively utilised tactics variously known as corporate campaigns, comprehensive campaigns, or strategic campaigns. These campaigns apply pressure on employers through customers, stockholders, boards of directors, and politicians. The objective is to impact the employer by way of its financial resources, business relationships with other organisations, and customer bases. In 
essence, the intent of such campaigns is to utilise non-traditional tactics in an attempt to pressure a firm's top policy makers to change the firm's behaviour.

Corporate campaigns have been used by unions for a variety of purposes, however, they seem to be most successful as part of organising drives (Jarley, 1990; Perry, 1987). In his study of 28 corporate campaigns, Jarley found that successful campaigns involve escalating pressures on an employer from multiple directions, deployment of corporate social responsibility issues, media coverage on sensitive public relations matters, and the involvement of government regulatory agencies. Furthermore, in almost every successful campaign, a particular incident closely coincided with the campaign settlement or the start of serious negotiations. The task for a union is to apply sufficient pressure to hurt a firm without harming the employment of the persons it is attempting to organise. Furthermore, a corporate campaign may succeed in lowering the resistance of an employer, but the union must still identify issues that have the power to persuade workers to vote for union representation. Corporate campaigns reflect the important roles that financial markets, regulatory legislation, public relations, and community action play in industrial relations. Although unions have a mixed record of results using corporate campaigns, at a time when unions are increasingly reluctant to apply pressure through work stoppages, it is likely that the use of corporate campaigns will be expanded.

The major challenge confronting American unions is to increase membership among whitecollar workers (sales, clerical, administrative, technical and professional). Currently, these workers comprise about 60 percent of the labour force, and the percentage will continue to increase. The changing composition of the American labour force already is reflected in union membership. In 1973, less than 24 percent of all union members were in white-collar jobs. By 1990, that proportion had grown to 45 percent of total union membership. To increase membership density, unions must present programmes, utilise procedures, and express values that appeal to moderate, educated, middle-class, white-collar workers. To date, results of organising efforts among white-collar workers are not impressive. Outside of government employment, public utilities, and hospitals, the level of white-collar unionisation is very low. For example, in the labour intensive financial, insurance, and real estate industries, union density is less than three percent. In the large retail and wholesale industries, union density is less than seven percent.

Women have much higher rates of employment in white-collar occupations compared to manual occupations. Therefore, success in organising women will be an important factor in the revitalisation of the American labour movement. Although the labour force participation rate of women has been increasing for many years, the female work force remains an elusive target for unions. Overall, there has been a slight decline in the percentage of unionised women workers. In 1985, 13.2 percent of working women were union members; by 1995, 12.3 percent. In contrast, the female component of total union membership has risen from 18.5 percent in 1956 to 41 percent in 1995 . The increase in the proportion of female union members is due largely to rapid growth in public sector unionisation during the 1960 s and 1970 s and reduced unionisation in the manufacturing sector during the $1980 \mathrm{~s}$. The service and public sectors have much higher levels of female employment compared to the manufacturing sector. 
Research shows that women are not less supportive of union representation than men (Cook, 1991; Fiorito, 1986; Leigh, 1987). To the contrary, non-union women in private sector, white-collar jobs (representing over half of the female non-union work force) express more interest than comparable men in joining unions. Given an opportunity to vote in a representation election, women appear to be more willing to vote for union representation than men (Schur, 1992). Significant changes in organising tactics are occurring among unions that are active in industries with large percentages of female workers (Crain, 1994), including hiring young, racially diverse, well-educated female organisers, focusing attention on issues of particular importance to working women (such as flexible work schedules), and building self-esteem and supportive relationships. These unions have enjoyed a disproportionate share of organising successes in recent years. Win rates in representation elections have been highest in bargaining units that are predominantly female.

Revised techniques and strategies certainly will play a role in successful organising among white-collar workers. More important, however, will be organised labour's accommodation with new methods for work organisation and managerial decision making. The underlying industrial relations system in the United States is, itself, in transition.

\title{
Employee participation programmes
}

The important studies of Freeman and Rogers (1994 and 1995) indicate that if unions are to stem the decline of organised labour in America, unions need to emphasise co-operation rather than confrontation. American workers do not want a hostile or class-conscious workplace. Summarising their findings, Freeman and Rogers (1995: 18) stated:

\begin{abstract}
"Most American employees want more involvement and greater say in their jobs. Many sometimes a majority, sometimes a large minority - also want some form of workplace organisation or policy that provides them with group as well as individual voice. Employees wish such organisation or policy to give them independent input into workplace decisions. A sizable minority wants union or union-like organisations; the majority, which favour joint consultative committees, want to be able to select their representatives to such committees.
\end{abstract}

At the same time, virtually all employees, including union members and those interested in joining unions, strongly prefer co-operative relations with management to conflictive ones, and are acutely sensitive to the need for management acceptance of representation and participation organisations or policies if those are to work."

For the most part, American unionists have a sceptical or ambivalent view of worker participation programmes initiated by employers. Many unionists regard these programmes as attempts by management to gain knowledge possessed by workers in order to increase productivity, reduce work rules, and, in general, gain concessions from unions without sharing decision making; in other words, consultation not co-determination. Hostile unionists characterise corporate-driven quality improvement programmes as a ploy by management to undermine collective bargaining or to avoid unionisation. American union leaders generally fear that employee involvement programmes weaken workers' commitment to, and identification with, unions (Craft, 1991). 
Traditional American unionists begin with the assumption that the union-employer relationship is adversarial, and that it is the function of the union to manage worker discontent and to channel protest. Effective militancy requires membership solidarity and strong leadership by the union. Inevitably, the exercise of sustained union advocacy evolves organisational structure, bureaucracy, and career unionists. Any programme or activity that is perceived as a threat to this control is viewed with concern by union leaders. Worker participation programmes confront union leaders with the need to shift their perspective, and to take a strategic, adaptive, and long-term view of relationships with management.

The task for unions is to effectively integrate collective bargaining with direct worker participation in the managerial function. A distinction is made here between management (the hired representatives of owners) and the managerial function. Progress in this direction will be uneven. Moreover, a number of factors, including the American culture, a highly competitive market economy, and deeply ingrained legal constructs, suggest that the underlying adversarial nature of union-management relations will persist. However, the blending of traditional, adversarial collective bargaining with participative activities would produce a significantly different industrial relations system, a system of co-management. The resulting system, confrontation surrounded with co-operation, would be far more appealing to the bulk of moderate, white-collar workers, than is the current industrial relations system. The necessary adjustments and accommodations, as unsettling as they would be for traditional unionists and their organisations, could be the basis for a renewed and expanding labour movement.

The concept of empowerment is spreading beyond high-tech professional workers, and is challenging existing employee relations structures in all sectors. Satisfaction with job elements, not traditionally emphasised by unions, has increased in importance. Thus, when attempting to organise workers, unions would benefit from giving greater emphasis to such non-traditional themes as their ability to improve job content and to enhance the effectiveness of worker participation in managerial decisions. Employees want more influence at their workplace, and generally recognise that group participation is necessary to influence management (Freeman and Rogers, 1994, 1995).

During the past decade, employers increasingly have established worker participation groups for consultive activities, mostly related to quality improvement (Juravich, 1993). Some employers have gone beyond quality issues and use their worker groups for a variety of problem solving purposes, including matters involving the terms and conditions of employment. In doing so, unions charge that employers violate federal labour law (Section 8a2, Labor Management Relations Act) by establishing and dealing with employer-dominated worker groups. The National Labor Relations Board's decision in the important Electromation, Inc. case (309 NLRB No. 163, 1992) sustained this charge. The Electromation decision calls into question the legality of a wide variety of worker participation activities unilaterally initiated by management for nonunion workers (Miller, 1996). Employers are attempting to use the current Republican controlled Congress to write more flexibility into this provision of the law. However, the threat of a veto by President Clinton has so far stalled the enactment of enabling legislation. The President has been responsive to union fears that any relaxation of the Section $8 \mathrm{a} 2$ restrictions would encourage non-union employers to use worker participation groups as part of their union avoidance tactics. 
It is becoming evident that, with intensified competition, employees prefer a co-operative workplace where the economic health of the enterprise is a priority. Strongly adversarial relationships are not effective in rapidly changing market economies that demand strategic planning, flexibility and innovation. Longer term pay offs and greater job security will accrue to unions and workers who accommodate change by engaging in genuine productivity bargaining. This realisation is gradually reshaping the American labour movement.

Driven by economic necessity, some unions are implementing proactive strategies that modify adversarial practices to accommodate technological and work method changes. The 1994 agreement between the Levi Strauss Company and the Amalgamated Clothing Workers union is an excellent example of such a strategy in an industry (apparel) where domestic and international competition is fierce. The company and the union are committed to comprehensive, joint participation in business planning, budgeting, technological innovation, and the organisation of work. Self-managed employee teams replace the old piecework system where people worked separately, each one performing a specific task such as sewing on pockets or zippers. As part of the agreement, management will not resist the union's organising activities throughout the company.

Union participation in co-management programmes is increasing throughout the American labour movement. Unions as diverse as the Communications Workers, the Amalgamated Clothing Workers, the United Automobile Workers, the United Steelworkers of America, and the International Association of Machinists are reshaping the basic nature of the industrial relations system and the meaning of adversarial collective bargaining. The various strategies for creating co-management share basic elements:

- Strong local unions actively involved with plant level management;

- Decentralised innovation and problem solving;

- Active employee involvement in decision-making (rather than a reliance upon union officials and management);

- Company investment in new technology and training;

- Work system redesign that looks at job content, organisational structures, information sharing, and union participation in decisions concerning new facilities and technology.

To date, the pace of change for American unions has been cautious and uneven. However, after years of resistance and scepticism, some unions are coming to view worker participation programmes and union co-management as methods to manage change, enhance job security, and increase membership.

\section{Employment security}

The full potential of worker participation programmes will be realised only if employees experience greater job security and a fair share of productivity gains. Enhanced employment security is emerging as a central feature of many negotiated co-management programmes. Typically, these programmes provide that in return for a union's co-operation in managing change (reorganising work, introducing new technology, retraining, relocating, etc.), most represented workers are protected from lay-offs for the duration of a collective bargaining 
agreement. American unions are coming to realise that employment security and competitiveness are the responsibility of all participants. In a dynamic market economy, the health of a company is the only real security for its employees.

An example of this emerging trend in collective bargaining is the 1994 agreement between the League of Voluntary Hospitals (with 40 member hospitals in the New York City region) and the National Health and Human Services Employees Union (representing 39,000 employees in the League's hospitals). In exchange for wide-ranging labour cost savings, the hospitals agreed not to lay off employees during the next three years. This protection applies to only full-time employees, with at least two years seniority at the date of the agreement. Additionally, employment levels could be reduced in each hospital through attrition. In the context of intense pressures from government, consumer groups, and businesses for medical cost containment, collective bargaining agreements with co-management and job security features are spreading throughout the unionised segment of the hospital industry.

By way of comparison at a very different type of work setting, the National Steel Company and the United Steelworkers of America have negotiated a co-management agreement labelled the "Co-operative Partnership Programme". Under the programme, union members participate in essentially all decision making in the company. Full-time employees, with at least one year seniority, are guaranteed they will not be laid off during the contract period. Similar comanagement programmes are emerging at other unionised firms in this troubled industry.

As unions move to promote membership and representation among white-collar workers, heightened employment security could become a major selling point. However, such protection for a firm's core work force would come at the expense of contingent workers (employed on a part-time, temporary or project basis) and low seniority workers.

\section{Concluding comments}

This assessment of the American labour movement leads to the following conclusions.

1. The factors that have weakened the labour movement during the past three decades will continue to impact unions for at least the remainder of this decade.

2. Unless Democrats make substantial gains during congressional elections in November 1996, there is little likelihood that unions will obtain long sought changes in labour legislation that would aid their organising activities. It remains to be seen if unions are willing to rely less on government assistance, and more on their own efforts. Employer resistance to union organising campaigns is extreme and intense. Some unions and the new leadership of the AFL-CIO are attempting to overcome this resistance by committing substantial resources to new organising techniques and highly focused organising projects.

3. To varying degrees, unions are reorienting their strategies and activities to reflect the interests of a work force that increasingly values co-operation rather than confront- 
ation, employment security through managed change, and participative management. The development of co-management programmes provides unions with opportunities to appeal in positive terms to the largely unorganised, middle-class, white-collar workers.

4. Co-management activities are evolving as part of collective bargaining in the United States, rather than as an alternative to it. As collective bargaining and co-management are integrated, confrontation is surrounded with co-operation. Nevertheless, the division of the economic pie is ultimately an adversarial process. Co-management will not relieve unions of the responsibility to develop and apply power as needed.

\section{References}

Bean, Ron and Holden, Ken (1992), Cross-national Differences in Trade Union Membership in OECD Countries, Industrial Relations Journal, 23(1): 52-59.

Bennett, James (1991), Private Sector Unions: the Myth of Decline, Journal of Labor Research 12(1): 1-12.

Chang, Clara and Sorrentino, Constance (1991), Union Membership Statistics in 12 Countries, Monthly Labor Review, 114(12): 46-53.

Cook, Alice (1991), Women and Minorities. In Strauss, George (ed.), The State of the Unions, Madison, WI: Industrial Relations Research Association.

Craft, James (1991), Unions, Bureaucracy, and Change, Journal of Labor Research, 12(4): 393-404.

Crain, Marion (1994), Gender and Union Organizing, Industrial and Labor Relations Review, 47(2): 227-248.

Curme, Michael, Hirsch, Barry and MacPherson, David (1990), Union Membership and Contract Coverage in the United States, 1983-1988, Industrial and Labor Relations Review, 44(1): 5-33.

Delaney, John (1991), The Future of Unions as Political Organizations, Journal of Labor Research, 12(4): 373-385.

Delaney, John (1990), Union Membership and Voting for COPE-Endorsed Candidates, Industrial and Labor Relations Review, 43(5): 621-635.

Fiorito, Jack and Greer, Charles R. (1986), Gender Differences in Union Membership, Preferences, and Beliefs, Journal of Labor Research, 7(2): 145-164. 
Freeman, Richard and Rogers, Joel (1994 and 1995), Worker Representation and Participation Survey, Princeton, NJ: Princeton Survey Research Associates.

Gifford, Courtney (1996), Directory of US Labor Organizations, 1996 Edition, Washington, DC: Bureau of National Affairs.

Hirsch, Barry and MacPherson, David (1996), Union Membership and Earnings Data Book 1995, Washington, DC: Bureau of National Affairs.

Jarley, Paul (1990), Union Corporate Campaigns: an Assessment, Industrial and Labor Relations Review, 43(5): 505-524.

Juravich, Tom (1993), Mutual Gains?: Labor and Management Evaluate Their Employee Involvement Programs, Journal of Labor Research, 14(2): 165-185.

Leigh, Duane and Hills, Stephen (1987), Male-Female Differences in the Potential for Union Growth Outside Traditionally Unionized Industries, Journal of Labor Research, 8(2): 131-142.

Miller, Ronald (1996), Employee Participation and Contemporary Labor Law in the United States, Industrial Relations Journal, 27(2): 166-174.

Perry, Charles (1987), Union Corporate Campaigns, Philadelphia, PA: Industrial Relations Research Unit, Wharton School, University of Pennsylvania.

Schur, Lisa and Kruse, Douglas (1992), Gender Differences in Attitudes Toward Unions, Industrial and Labor Relations Review, 46(1): 89-102.

Wiatrowski, William (1994), Small Businesses and Their Employees, Monthly Labor Review, 117(10): 29-35.

Williamson, Lisa (1995), Union Mergers: 1985-1994, Monthly Labor Review, 118(2): 18-25. 